\title{
輻射加熱による構造要素試鍳装置と一実臨結果*
}

\section{A Rapid Radiant Heating Apparatus and an Experiment on the Thermal Deformation of Clamped Square Plate}

植 村 益 次**・砂川 惠**

Masuji Uemura, Megumi Sunakawa

冬木 稳**

Minoru FUYUKI

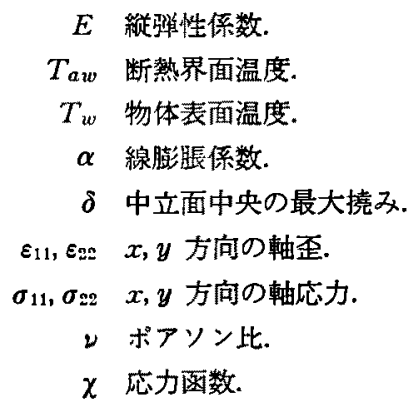

添字“ “ $x$ ”, “ $y$ ”はそれぞれ $x, y$ に関する偏微分を意 味する. 添字“ “P”, “ $F ”$ はそれぞれ平板，縁材に関 する量を示す，上線“一”は中立面成分を示す。

\section{2. 輻射加等装置の概要}

2. 1 系統ならびに期作原理 本䒾置は, 高速飛行 体の構造模型あるいは構造要素に, 飛行中に起こるの と相似な加熱状態を与えるものであって, 加熱源とし て赤外線ランプを使用し，これを相似型電子計算機の 手法により制御を行ない，定量的な熱発生を行なうこ とが可能である. 第 1 図に本装置の系統の概要を示

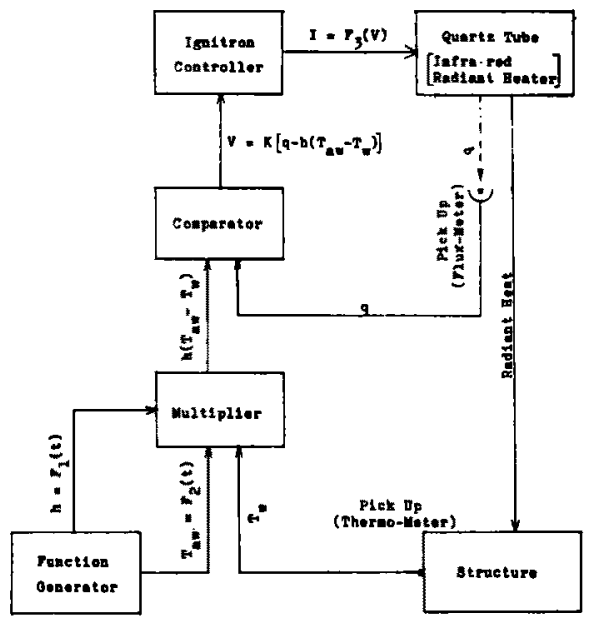

第 1 図 急速輻射加熱装置の系統 


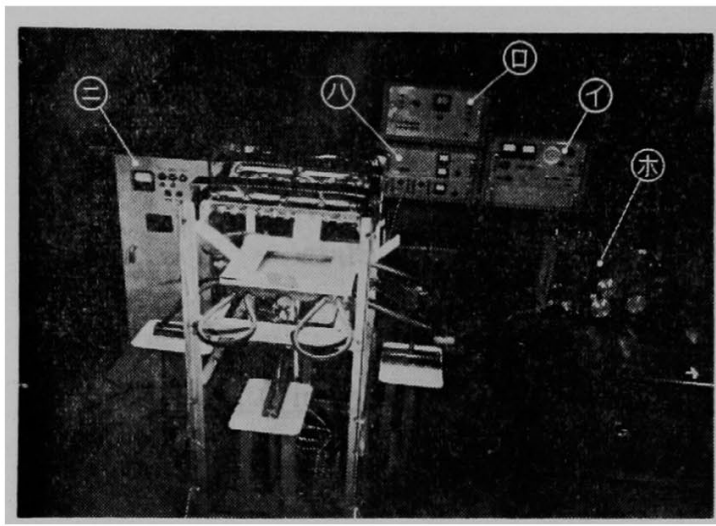

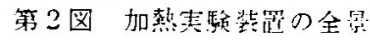

\section{し，第 2 図に実駼装置の全景を示す。}

本装置は試験体の表面に (2・1) 式の関係を保つ熱入 速度 $q$ を定量的に与える.

$$
q=h\left(T_{a w}-T_{w}\right) .
$$

(2.1) 式および第 1 図において，hおよび $T_{a w}$ は 飛行体の速度，高度，基準点からの位置扰よび表面の 状態等の函数であるが，これらは飛行状態によって求 められるので時間の函数と考え，あらかじ函数発生 器に設定して発生させる. $T_{w}$ は試験体にとりつけた pick up により電王の形で測定される. そして，乗算 器においてまず $\left(T_{a w}-T_{w}\right)$ の潰算が行なわれた後に $h\left(T_{a w}-T_{w}\right)$ が作られ, 比較器に入る. 比較器は高 利得差動增幅器であって, flux meter で測定した輻射 加熱器の発生熱量 $q$ と乗算器からの $h\left(T_{a w}-T_{w}\right)$ と を比較し，その差に対応する出力電圧Vをイグナイト ロン制御器に与える、イグナイトロン制御器の出力電 流はVによって変化し, 㬏射加熱器に流入する笔力が 操作されるので, $V=0$ すなわち $q=h\left(T_{a w}-T_{w}\right)$ の 関係が常に成立するように，自動的な制御が行なわれ 3.

2.2 轌成 本加熱装置はつぎのものより構成され る.
i) 函数発生器
ii) 乘算器
iii) 比校器
iv）イグナイトロン制御器
v）加熱ランブおよび支持台
vi）電源

以下簡単にこれらを説明する.

i) 函数発生器（第 2 园の (1), 第 3 図)——本器は ポテンショメータから数多くのタップを出しこれに 函数に対応する電王を設定し,このポテンショメータ の摺動子を一定速度で駆動することによって，任意の 函数波形を折れ線で近似する置である.

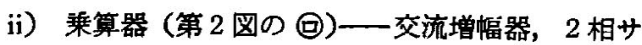

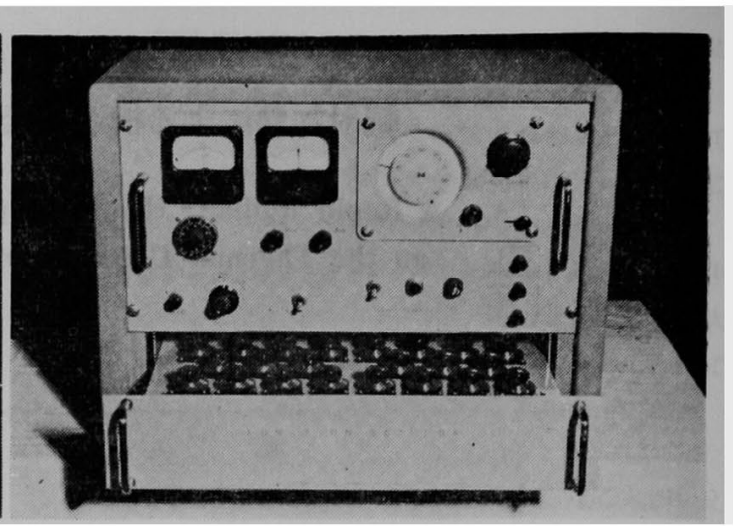

第3図面数軓尘器

一ボエータおよび 4 連ポテンショメータから構成さ れ，相似型電子計算機の乘算要素として使用されるも のである.

iii）比較器（第 2 図の）-一本器は二つの符号の 異なる䉓圧の絶対値を比較して，その差に相当する電 王を発生する装置であって，相似型電子計算機の加算 器に相当する装置か２ 組組み迈まれている.

iv）イグナイトロン制徂器（第 2 図の€，第 4 図） 一一本器は輻射加熱器に与える䉓力を $0 \sim 20 \mathrm{KW} の$

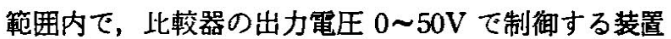
であり，交流 50c/s の各サイクルにおいて，その点抔 すべき位置を比較器からの入力電圧で定まるサイラト ロン回路のパルス位相で与え, 入力龟圧に相当する出 力電流を連続的に発生するようになっている.

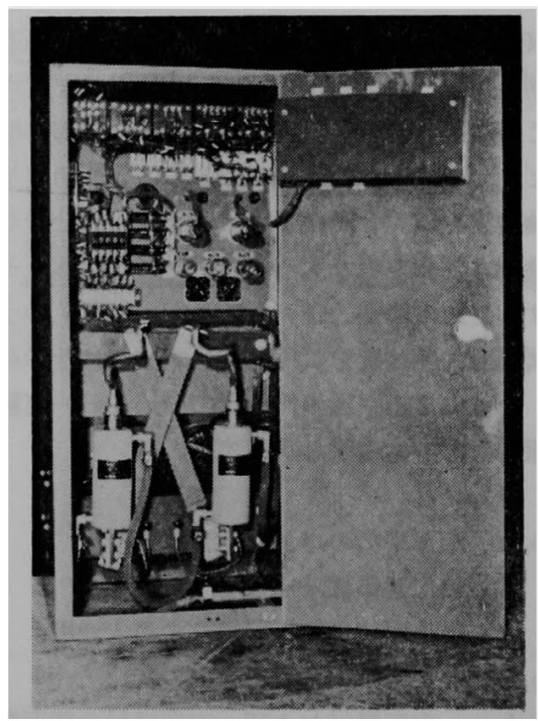

第 4 㘝イブナイトロン制御器の内部

この方式は可飽和コア・リアクトルカ式に較へ感応 時間も早く, 念速な過渡的加熱状態をシミュレートす るのに適している.つぎに制御回路の原理についてゃ や詳しく説明する. 
a）点弧回路：負荷回路に逆並列に接綍した 2 本の イグナイトロン IG 1, IG 2 (第 5-1図)およびイグナ イトロンを点弧させるサイラトロン TH 1, TH 2 の対 称なる一対の回路から構成されている. その中の IGI ク゚ループについて述へる (IG 2 は全く同じ). 第 5-2 図は IG 1 グループの点弧回路の原理回路てある.す なわち, TH 1 の格子-陰極間に常時 $E_{B}$ なる負のパ イアス電压が那加されているのて，TH1 は放電しな い状態にある．また陽極一陰極間にはコンデンサ C の 充電電珐が印加されている状態にある.このような状 態にあるとき IG 1 の陽極に正の交番電王が加わった とすると, キック・トランス TR2 に負のパイアス電
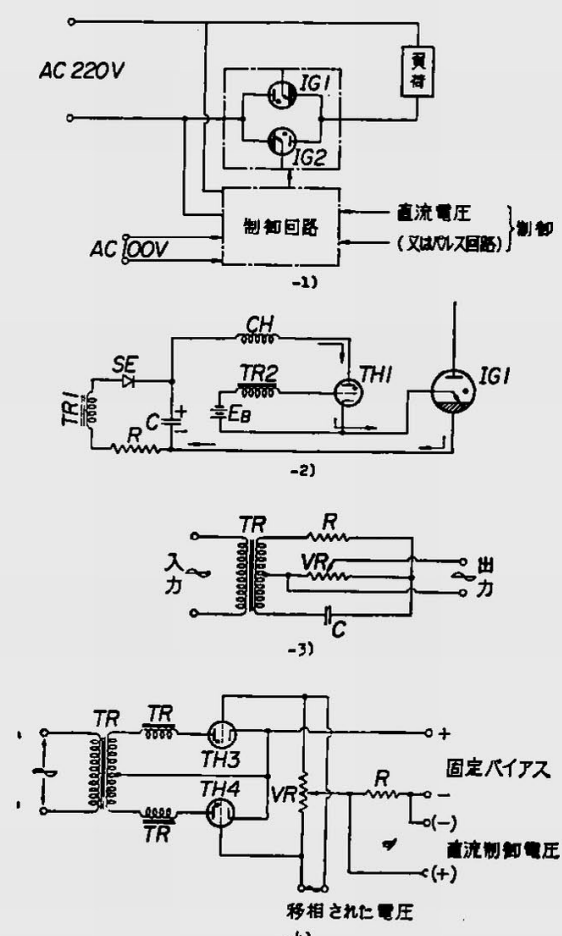

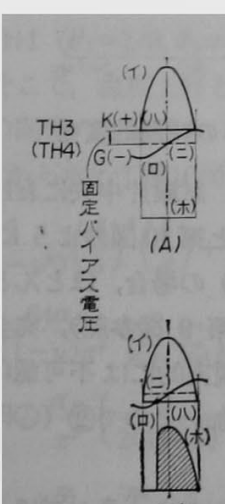

(D)

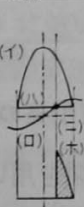

(B)

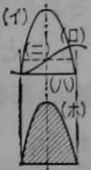

(E)

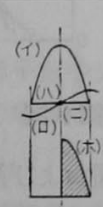

(C)
電流波形(た)は振 抗負得の场合の 波形である TH3,TH4の鳃界 格子電压は福略

$-5)$

第5困 イデナイトロン制御器の原理説明区
圧 $E_{B}$ に打ち勝つキック電压を発生せしめれば TH 1 は導通し、コンデンサCの電珐は $\mathrm{CH} \rightarrow \mathrm{TH} 1 \rightarrow \mathrm{IG1}$ の 順に流れ放電する.このときイグナイタはイグニッシ ョンするのて IG 1 は通䉓となる. TR 2 に発生せし めるキック位相を，つぎに述べるうに IG 1 の交番 電圧位相の適当なところて発生させれば, IG 1 の通 電の時期を制御することがでる。

b）位相制御回路：本回路は，点弧回路で述へたキ ック電圧の位相をイグナイトロン電圧位相に合わせて そのキック位相を制御する回路である．第 5-3 図は一 般的に用いられている CR の位相回路てあって，入力 電圧位相（IG 1，IG2 と同相）に対し出力電圧位相を $90^{\circ}$ 遅らせるよう抵抗Rにより調整されている。また VR は移相された出力電圧の大きさを変化せしめるよ 3になっている. 第 5-4 図の TH 3,TH 4 の回路はキ ック電圧位相を変化させる回路である.

c) 直流固定ハイイス回路：本回路は定電圧故電管 による固定バイアス回路て，TH 3、TH4 の格子-陰 極間に負のバイアスを加えている：この負のパイアス 電圧と直流制御電圧は第 5-5 图のごとくなる. いま直 流估定バイアス電压に対し打ち消すように直流制御電 王を加えると，イグナイトロンの負荷電流は(体の斜線 波形のごとく変化する. (A) 図の心の直線は直流制 御電圧が零の場合であって, 負荷の電流も零であるが， (E) 図の $\Leftrightarrow$ の直線は直流固定バイアスを十分打ち消 して TH 3 (TH 4) の格子を（十）にして(1)の波形に 対して移相された電圧波形を（E）図のごとくのせる ことになるのて負荷㲠流は最大になる，このように直 流制御電圧を制御することによってイグナイトロンの 通電の位相が制御されるのが分かる，すなわち，負荷

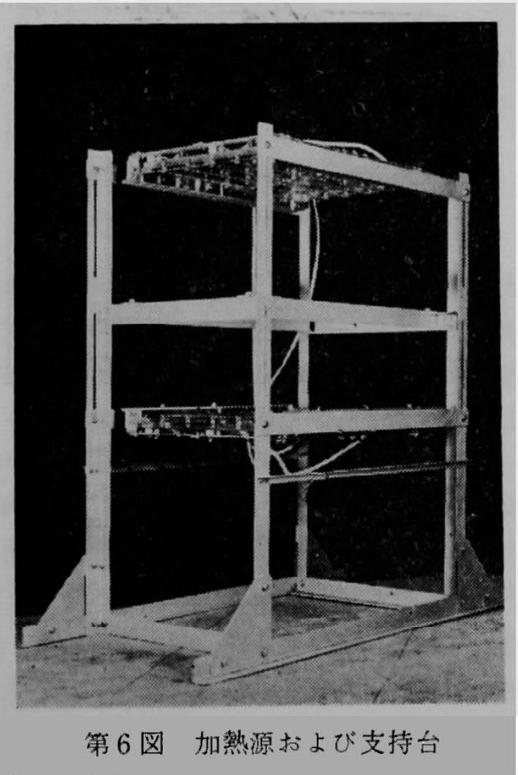


電流を零より最大まで連続的に変化させる目的を達し ている.

v）加熱ランプおよび 支持台（第6 図)一一加熱器 は石英赤外線ランプ [直径 $3 / 8 \mathrm{in}$, 長さ 10 in で, $1 \mathrm{KW}$ (230 Volt) または $3 \mathrm{KW}(460$ Volt)] 密に配列し たもので,イグナイトロン制御芰によって点火され， 制御可能の熱流を試験体に供給する．本装置では反射 板のついた支持枕に 10 本ずつ組み込まれ，上下に対 向して支持台にとりつけられているが，片方の支持枠 に20本全部を組み込むこともでる. 試験体との距 離は調節可能である.

vi）電 源

\begin{tabular}{|c|c|c|c|c|c|}
\hline 函 & 数 発 & 器 & $\begin{array}{c}\mathrm{DC} \\
" \prime \\
\mathrm{AC}\end{array}$ & $\begin{array}{r} \pm 12 \\
24 \\
100\end{array}$ & 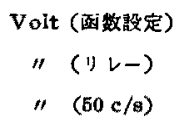 \\
\hline 乗 & 算 & 器 & $\mathrm{AC}$ & 100 & Volt $(60 \mathrm{c} / \mathrm{s})$ \\
\hline 比 & 輍 & 器 & AC & 100 & Volt $(50 \mathrm{c} / \mathrm{s})$ \\
\hline 17t & $+1+0$ & Aา: & ${ }^{A C}$ & $\begin{array}{l}100 \\
220\end{array}$ & $\begin{array}{c}\text { Volt }(50 \mathrm{c} / \mathrm{s}) \\
\|(\|)\end{array}$ \\
\hline
\end{tabular}

\section{3. 実鍠}

上記の加熱装置を用い, 四辺固定正方形平板の熱変 形についての一実験を行なった。

\section{1 赛駼の概要}

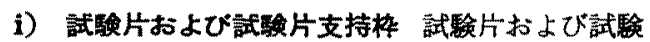
片支持枠は，それぞれ 18/8 耐第鋼および砲金で作製 し，支持杵内部には冾却水を通して，試験片中央部と

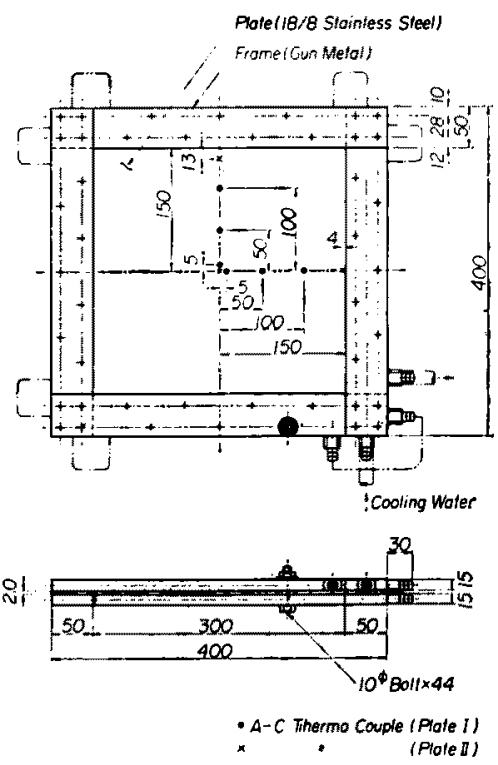

第 7 図試験片および試駼片支持枠
周辺部との間に温度変化を与えることができるように してある. その大要を第 7 図に示す。

ii）温度上界および撓みの測定 試駼片内の温度 上昇は $\mathrm{A}-\mathrm{C}$ 熱電対にて測定し，電磁オッシログラフ （第 2 図の用）で記録する．温度测定点を第 7 困に同 時に示す.

試験片中央の撓みは dial gauge で読す。

iii）加熟実験 支持枠に通水して試験片（正方形 平板）全体と支持枠の温度がすへて一様になった後支 持枠て周辺を固定した試験片を加熱器の支持台に载 せ，赤外線ランプに点火する. 赤外線ランプは 20 本 全部を試験片上方 $300 \mathrm{~mm}$ のランプ支持枠にとりつ け，試験片中央の摬み $0.25 \mathrm{~mm}$ おきに温度を記録す る.

3. 2 実駼結果およひ理論值との比較梲討 加熱は 試駼装置の全容量 $20 \mathrm{KW}$ を使って試験片の上面より 行ない，step 函数で与えた，試駼片中央における温度 上其および暁みの時間的変化を第 8 図および第 9 図に 示す.なお，加熱のごく初期を除いて，試験片上下面 間に温度差は認められず, ランプが全出力に達するま ての時間は約 $1 \mathrm{~s}$ だあった.

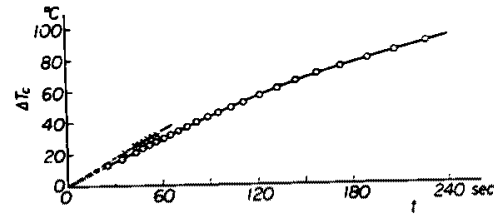

第 8 图平板中央における温度の時間的変化

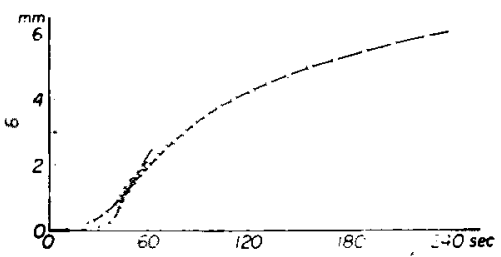

第 9 図平板中央の暁みの時間的変化

第 8 图招よび第 9 図を用いて，試験片中央における 温度上昇と暁みとの関係を示すと第 10 图のようにな る.第 10 图に执いて(1)（X印）の場合，ほとんど挫 屈に近い現象が観察されたが（第 9 図参照），完全に flat な平板を使用することは現実的には不可能に近 く，一般には初期变形の影響が加わるので(2)(O印) の上らな曲線が得られる。

試駼片支持枠は通水してて冷却した上，ランプにより 直接加熱されるのを防ぐため木板の上にジラルミン 板を張ったカバーで覆ったが，平板内の温度分布を示 すと第11図のようになる.この平板内の温度分布は近 


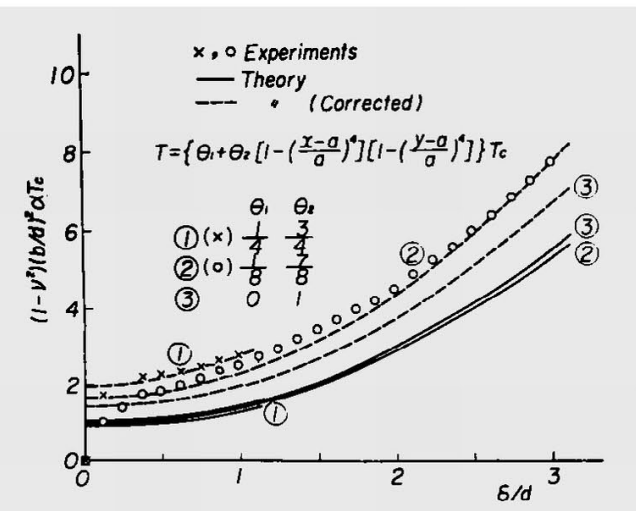

第10図平板中央に抢ける温度上昇と暁みの関係 $\alpha=17.1 \times 10^{-6}$

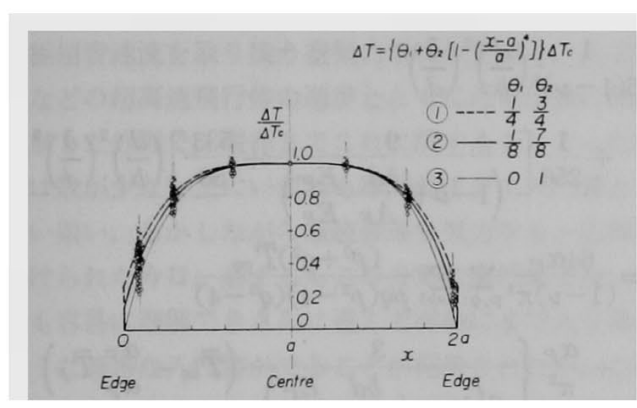

第11図平板酤内の温度分布

似的に次式で表わすことができる。

$$
T=\left\{\theta_{1}+\theta_{2}\left[1-\left(\frac{x-a}{a}\right)^{4}\right]\left[1-\left(\frac{y-a}{a}\right)^{4}\right]\right\} T_{C}
$$

筆者らの一人”が前に報告した理論解析における数値 計隽例では 2 次項をもつ扰物線状の面内温度分布を仅 定したか，実駼結果では4次項で表わされるようであ る. 第10困の実験結果に批いて, (1) ( $\times$ 印) の場合の 温度分布は $\left(\theta_{1}=1 / 4, \theta_{2}=3 / 4\right)$ に近く, (2)(O印) の 場合は $\left(\theta_{1}=1 / 8, \theta_{2}=7 / 8\right)$ に近い.

そこて，温度上昇と四辺固定正方形平板中央の撓み との関倸の理論值を，(1)および (2)の場合に対し，次 式”から求めて第10図に実線で示す。

$$
\begin{aligned}
& \overline{6\left(1-\nu^{2}\right)}\left(\frac{d}{b}\right)^{2}\left(\frac{\delta}{d}\right)+\frac{1}{256}\left[\frac{9}{(1-\nu)}+\frac{533}{50}\right]\left(\frac{d}{b}\right)^{2}\left(\frac{\delta}{d}\right)^{3} \\
& =\frac{64 \alpha_{P}}{(1-\nu) \pi^{4}} \sum_{p, q} \sum \frac{\left(p^{2}+q^{2}\right) \widetilde{T}_{p q}}{p q\left(p^{2}-4\right)\left(q^{2}-4\right)} \\
& \quad+\frac{\alpha_{P}}{\pi^{2}}\left\{\frac{3}{2(1-\nu)} \bar{T}_{00}-\frac{1}{8}\left[4\left(\bar{T}_{02}+\bar{T}_{20}\right)\right.\right. \\
& \\
& \left.\left.-\left(\bar{T}_{04}+\bar{T}_{40}\right)\right]+\frac{\bar{T}_{22}}{4}-\frac{1}{20}\left(\bar{T}_{24}+\bar{T}_{42}\right)\right\}\left(\frac{\delta}{d}\right),
\end{aligned}
$$

$$
\begin{gathered}
\bar{T}_{00}=\frac{1}{4 a b} \int_{0}^{2 b} \int^{2 a} \bar{T} d x d y, \\
\bar{T}_{i 0}=\frac{1}{2 a b} \int_{0}^{2 b} \int_{0}^{2 a} \bar{T} \cos \frac{i \pi x}{2 a} d x d y, \\
\quad(i=2,4, \cdots, \text { even }), \\
\bar{T}_{0 j}=\frac{1}{2 a b} \int_{0}^{2 b} \int_{0}^{2 a} \bar{T} \cos \frac{j \pi y}{2 b} d x d y, \\
\bar{T}_{i j}=-\frac{1}{a b} \int_{0}^{2 b} \int_{0}^{2 a} \bar{T} \cos \frac{i \pi x}{2 a} \cos \frac{j \pi y}{2 b} d x d y, \\
\quad(i, j=2,4, \cdots, \text { even }), \\
\bar{T}_{p q}=\frac{1}{a b} \int_{0}^{2 b} \int_{0}^{2 a}\left(\tilde{T}-\tilde{T}_{e}\right) \sin \frac{p \pi x}{2 a} \sin \frac{q \pi y}{2 b} d x d y, \\
\quad(p, q=1,3,5, \cdots, \text { odd })
\end{gathered}
$$

理論值（実線）と実龭值はかなりの得隔があるが（3 -2) 式からの計算結果は縁材の伸びを無視した場合に 対するものであり，しかも理論值と実䍄値との差が直 線的であることから，この相違は粶材の内力および温 度上昇による伸びに起因するものと考えられる.すな わち, 縁材に椧却水を通して温度の定常化を図ったか， 第 11 図に見られるように板縁において温度上异があ り，また縁材の面内方向の変位を測定したところ第 12 図のようになり，加熱初期から縁材の侦びが認められ た. この種の実験としては，林教授2゙による面圧力と 板内内力を弓ける板の撓みに関する実験があり，理論

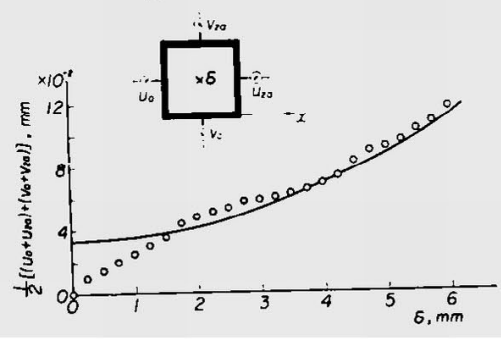

第12図平板中央の挬みと縁材中央の 面内変位との関係

計算と比較しておられるが，その場合にも暁みと面内 歪 (応力) との間に一定量の相傕があり，縁材の曲げ 変形を考虑することによってその不一致は良く説明さ れた。しかし本实㖵ては，第 7 図からむ分かるように 縁材の板面内の曲げ剛性はきわめて大きいので，曲げ 変形は無視して加熱後む縁材は直線状を保つと考え, さらに面に垂值力向の変位も無視し，縁材の内力およ び温度上昇による伸びに対する補正計算を行なう.

いま，第12図におけるがごとく縁材て補強された平 板を考えると，面内における力および歪の間につぎの 諸式て与えられる関係が近似的に成立する。 


$$
\left.\begin{array}{r}
\int_{0}^{2 b}\left(\bar{\sigma}_{11}\right)_{P} d \cdot d y+2\left(\bar{\sigma}_{11}\right)_{F} A_{1 F}=0, \\
\int_{0}^{2 \alpha}\left(\bar{\sigma}_{22}\right)_{P} d \cdot d x+2\left(\bar{\sigma}_{22}\right)_{F} A_{2 F}=0,
\end{array}\right\}
$$

ここて， $\left(\bar{\sigma}_{11}\right)_{P}$ および $\left(\bar{\sigma}_{22}\right)_{P}$ は平板の適合条件式か ら求めた次式"の $\chi$ により与えられる.

$$
\begin{aligned}
& \left(\bar{\sigma}_{11}\right)_{P}=\chi_{y y}, \quad\left(\bar{\sigma}_{22}\right)_{P}=\chi_{x x}, \\
& \chi=\frac{C_{1}}{2} x^{2}+\frac{C_{2}}{2} y^{2}+\frac{E \delta^{\prime 2}}{2}\left\{\left(\frac{a}{b}\right)^{2} \cos \frac{\pi x}{a}+\left(\frac{b}{a}\right)^{2} \cos \frac{\pi y}{b}\right. \\
& -\frac{1}{16}\left[\left(\frac{a}{b}\right)^{2} \cos \frac{2 \pi x}{a}+\left(\frac{b}{a}\right)^{2} \cos \frac{2 \pi y}{b}\right] \\
& -\frac{2\left(\frac{a}{b}\right)^{2}}{\left[1+\left(\frac{a}{b}\right)^{2}\right]^{2}} \cos \frac{\pi x}{a} \cos \frac{\pi y}{b} \\
& +\frac{\left(\frac{a}{b}\right)^{2}}{\left[1+4\left(\frac{a}{b}\right)^{2}\right]^{2}} \cos \frac{\pi x}{a} \cos \frac{2 \pi y}{b} \\
& \left.+\frac{\left(\frac{a}{b}\right)^{2}}{\left[4+\left(\frac{a}{b}\right)^{2}\right]^{2}} \cos \frac{2 \pi x}{a} \cos \frac{\pi y}{b}\right\} \\
& +E \alpha\left\{\sum_{i=2}^{\infty} \frac{\bar{T}_{t 0}}{\left(\frac{i \pi}{2 a}\right)^{2}} \cos \frac{i \pi x}{2 a}+\sum_{j=2}^{\infty} \frac{\bar{T}_{0 j}}{\left(\frac{j \pi}{2 b}\right)^{2}} \cos \frac{j \pi y}{2 b}\right. \\
& \left.+\sum_{i=2}^{\infty} \sum_{j=2}^{\infty} \frac{\bar{T}_{i j}}{\left[\left(\frac{i \pi}{2 a}\right)^{2}+\left(\frac{j \pi}{2 b}\right)^{2}\right]} \cos \frac{i \pi x}{2 a} \cos \frac{j \pi y}{2 b}\right\}, \\
& \text { ここに } \quad \delta^{\prime}=\frac{\delta}{4}
\end{aligned}
$$

(3.4) (3.9) の諸式から， $C_{1}$ および $C_{2}$ は, $A_{1 F}=A_{2 F} \equiv A_{E}, a=b$ として次式て与えられる.

$$
\begin{aligned}
& C_{1}=C_{2}=-\frac{E_{P}}{\left(1-\nu+\frac{b d}{A_{F}} \frac{E_{P}}{E_{F}}\right)}\left[-\left(\alpha_{F} \bar{T}_{00}-\alpha_{F} \bar{T}_{F}\right)\right. \\
& \left.+\frac{3 \pi^{2} \delta^{\prime 2}}{8 b^{2}}\right]
\end{aligned}
$$

縁材の伸びを考應した場合，温度上界と四辺固定正方 形平板中央の 撓みとの関係は，(3・11）式を用いて, （3.12）式の積分を行なって, (3.14) 式て与えられる.

$$
\begin{aligned}
& \int_{0}^{2 b} \int_{0}^{2 a}\left[D \nabla^{4} w-d\left(\chi_{y y} w_{x x}-2 \chi_{x y} w_{x y}+\chi_{x x} w w_{y y}\right)\right. \\
& \left.+\frac{E d^{2} \alpha}{(1-\nu)} D^{2} \bar{T}\right]\{w\} d x d y=0 \\
& \Xi こ に \\
& w=\delta^{\prime}\left(1-\cos \frac{\pi x}{a}\right)\left(1-\cos \frac{\pi y}{b}\right) \\
& \frac{1}{6(1-\nu)^{2}}\left(\frac{d}{b}\right)^{2}\left(\frac{\delta}{d}\right) \\
& +\frac{1}{256}\left[\frac{9}{\left(1-\nu+\frac{b d}{A_{F}} \frac{E_{P}}{E_{F}}\right)}+\frac{533}{50}\right]\left(\frac{d}{b}\right)^{2}\left(\frac{\delta}{d}\right)^{8} \\
& =\frac{64 \alpha_{P}}{(1-\nu) \pi^{4}} \sum_{p, Q}: \sum_{\text {sild }} \frac{\left(p^{2}+q^{2}\right) \widetilde{T}_{p q}}{p q\left(p^{2}-4\right)\left(q^{2}-4\right)} \\
& +\frac{\alpha_{P}}{\pi^{2}}\left\{\frac{3}{2\left(1-\nu+\frac{b d}{A_{F}} \frac{E_{P}}{E_{F}}\right)}\left(\bar{T}_{00}-\frac{\alpha_{F}}{\alpha_{P}} \bar{T}_{F}\right)\right. \\
& -\frac{1}{8}\left[4\left(\bar{T}_{02}+\bar{T}_{20}\right)-\left(\bar{T}_{04}+\bar{T}_{40}\right)\right] \\
& \left.+\frac{\bar{T}_{22}}{4}-\frac{1}{20}\left(\bar{T}_{24}+\bar{T}_{42}\right)\right\}\left(\frac{\delta}{d}\right)
\end{aligned}
$$

（3.14）式において,板材は 18/8 而熱鋼, 縁材は硠金て あるから， $E_{P}=20,400 \mathrm{~kg} / \mathrm{mm}^{2}, E_{F}=9,500 \mathrm{~kg} / \mathrm{mm}^{2}$; $\alpha_{P}=17.1 \times 10^{-6}, \alpha_{P}=18.3 \times 10^{-6}$ とし, 第 7 図の諸元 を用いると，第10困の破線で示した補正曲線が得られ る. この近似的補正值と実駼結果との一致はきわわて 良好と考えられる。は，緑材の面内力向の変位は， (3.4) (3.11) の諸式から次式のよろになる.

$$
u_{F}=v_{F}=\left(\alpha_{F} \bar{T}_{F}-\frac{b d}{A_{F}} \frac{C_{1}}{E_{F}}\right) \times 2 b
$$

（3.15）式を第 12 図に実線で示すが，测定值と良好に 一致している.

なお，縁材の温度上昇を無視した場合の計算結果を 第 10 図に参考のため示しておく（3).

\section{4.あとがき}

本報告においては，小型の輻射加熱置およびそれ を用いての一実験について述へだすす，急速楅射加 熱装置の概要を記しその作動原理を锐明した.イグナ イトロン制御方式による本装置はきわめて良好に作動 し，本方式は，その後整備された容量 $200 \mathrm{KW}$ の大型 加熱装置にも採用された。つぎにこの装置を用いて 
行なった四辺固定の正方形平板の熱变形実駼について 述へた．実験により求めた温度上算と接みとの関係 は，理論解析結果りに縁材の伸びを近似的に補正した 結果上良好に一致することが示された。

最後に，本堹射加熱装置の整作にお忖る松下通信工 業株式会社研究部各位の御尽力に対し厚く謝意を表す る.

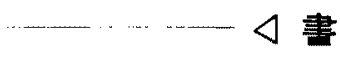

Introduction to Hypersonic Flow（極超音速流 入門) G.G. Chernyi (R.F. Probstein 訳ならびに編 集), Academic Press (New York and London 1961), $\mathrm{X}+262$ 頁.

極超音速流を取り扱う空気力学はロケット，人工衛 星などの超高速飛行体の進歩とともに近年急速に開括 発展した分野で，現在までこれに関するまとまった著 夆は数が少ない上にいずれも専門的すぎて入門書とは いい難い，しかしながら極超音速空気力学も一応体系 ゔけられた今日，必ずしもこの分野の専門家でない人 でむ容易に理解でさらに進んで詳細にまで入り得る ような適当な入門書がでることが期待されたが，この 本はまさにそのような趣旨に沿って書かれているとい える. 原著はロシヤ語で 1959 年 Moscow で出版さ れた. Chernyi は Sedov 門下の専門家であるから内 容は特に韭粘性理想気体の極超音速流のうち物体まわ りの流れの解析に重点がおかれソヴェトにおけるュニ 一クな研究結果を主題の一部になっている.この本は Hypersonic Flow (Academic Press) t Hayes ととも に書いたProbstein が原著者と密接な交涉をるって， 原着の多くの疑わしい点不明な点支明確にして訳と編

\author{
交献

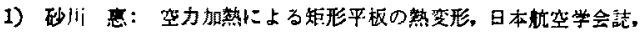 \\ 9 (1961), 37.

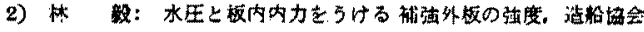 \\ 会報, 81 (1949), 99.
}

評

集をした上で出版された，序では極超音速空気力学が 有用になる超高速飛行体の速度範囲, 形式などにふれ, 実際の空気が遭う高温における種々の現象を取り上 げその効果についてごく概諭を述へて，第 1 章ては極 超音速流の特徴と相似則，第 2 章で先のとがった物体 まわりの流れを中心に非定常流との equivalence principle をかなり多くの図，表を用いて説明している. 第 3 章ではニュートン則，接線円錐法 (tangent-cone method)，プーゼマン則などの簡略公式を実験との比 較を多く用いて物理的な理解を助けるように紹介し て，最後に “boundary-layer method" を衙慗層 （shock layer）と境界層との類似を基に矮，円錐のま わりの流れに応用した例をあげている．第 4 章はいわ ゆる shock-expansion 法について，第 5 章は先のにふ い物体について特に先端のまるみの流れ方の影響を述 へててる．以上の他各章ごとの文献が巻末にのせられ ている.全体を通して特に第 2 章の equivalence principle，第 3 章の boundary-layer method，第 5 章はこの 本を入門書としてばかりでなく専門書としても十分な 好著としているよう評者には思われる。

(小口伯郎)

\section{抄録（続き）}

(104面より绕く)

能の単段厈縮機についてその形状を任意に変化させた とき速度や流れの状熊が設評点から広く㫿れた籍国に わたっての性能を計算機で間単に求める方法が確立さ れていればそれを重ね合わせて多段特性が得られるこ とになる. ここではまず equivalent diffusion parameter と momentum thickness との関係やこれにおい
て除かれる shock loss の扱い方等を述へ，半佳方向の 運動量平衡式を連統，エネルギー，状態，断熱等の方 程式と結合させて digital computer て解くべき方程式 を導く手順や計算順序が示されている，最後に実際の 迷音速単段による実験値と計算值との比較データが揭 げられている。

(花村 唐治) 